University of Nebraska - Lincoln

DigitalCommons@University of Nebraska - Lincoln

USDA National Wildlife Research Center - Staff Publications
U.S. Department of Agriculture: Animal and Plant Health Inspection Service

2010

\title{
Evaluation of harassment of migrating double-crested cormorants to limit depredation on selected sport fisheries in Michigan
}

\author{
Brian S. Dorr \\ USDA/APHIS/WS National Wildlife Research Center, brian.s.dorr@aphis.usda.gov \\ Ashley Moerke \\ Michael Bur \\ Chuck Bassett \\ Tony Aderman
}

See next page for additional authors

Follow this and additional works at: https://digitalcommons.unl.edu/icwdm_usdanwrc

Part of the Environmental Sciences Commons

Dorr, Brian S.; Moerke, Ashley; Bur, Michael; Bassett, Chuck; Aderman, Tony; Traynor, Dan; Singleton, Russell D.; Butchko, Peter H.; and Taylor, Jimmy D. II, "Evaluation of harassment of migrating doublecrested cormorants to limit depredation on selected sport fisheries in Michigan" (2010). USDA National Wildlife Research Center - Staff Publications. 904.

https://digitalcommons.unl.edu/icwdm_usdanwrc/904

This Article is brought to you for free and open access by the U.S. Department of Agriculture: Animal and Plant Health Inspection Service at DigitalCommons@University of Nebraska - Lincoln. It has been accepted for inclusion in USDA National Wildlife Research Center - Staff Publications by an authorized administrator of DigitalCommons@University of Nebraska - Lincoln. 


\section{Authors}

Brian S. Dorr, Ashley Moerke, Michael Bur, Chuck Bassett, Tony Aderman, Dan Traynor, Russell D.

Singleton, Peter H. Butchko, and Jimmy D. Taylor II 


\title{
Evaluation of harassment of migrating double-crested cormorants to limit depredation on selected sport fisheries in Michigan
}

\author{
S. Dorr Brian ${ }^{a, *}$, Ashley Moerke ${ }^{b}$, Michael Bur ${ }^{c}$, Chuck Bassett ${ }^{d}$, Tony Aderman ${ }^{\mathrm{e}}$, Dan Traynor ${ }^{\mathrm{b}}$, \\ Russell D. Singleton ${ }^{a}$, Peter H. Butchko ${ }^{f}$ Jimmy D. Tayior II ${ }^{\mathrm{g}}$ \\ "U.S. Department of Agriculture, Wildlife Services, National Wildlife Research Center, P.O. Box 6099. Mississippi State University, MS 3.9762, USA \\ b Lake Superior State University, 650 W, Easterday Ave., Sault Ste. Marie, MI 49783, USA \\ ' USGS Great Lakes Science Center, Lake Erie Biological Station, 6100 Colunibus Ave. Sandusky, OH 44870-8329, USA \\ U.S. Forest Service, 2727 N, Lincoln Road, Escanaba, MI 49829. USA \\ "Wildlife Services, 1865 O'Rourke Blvd., Suite C, Gaylord, MI, 49735, USA \\ 'Wildlife Services, 2803 Jolly Road, Suite 100, Okemos, MI, 48864, USA \\ : U.S. Department of Agriculure, Wildlfe Services, National Wildiffe Research Center, 9730-B. Lathrop Industrial Drive SW, Olympia, WA 98512, USA
}

\section{A R TICL E. IN F O}

\section{Article history:}

Received 3 June 2009

Accepred 17 November 2009

Communicated by Martin Stapanian

\section{Index words:}

Cormorants

Control

Management

Migration

Preclation

Fisheries

\begin{abstract}
A B S TRACT
Diverse management techniques have been used to mitigate conflicts between humans and double-crested cormorants (Phalacrocorax auritus) including harassment methods supplemented by lethal take. In this study we evaluated impacts of programs to harass spring migrating cormorants on the walleye (Sander vitreus) fishery. in Brevoort Lake and the yellow perch (Perca flavescens.s) and walleye fisheries at Drummond Island. Cormorant foraging declined significantly $(p<0.05)$ at both locations subsequent to initiation of harassment programs. Overall harassment deteried $90 \%$ of cormorant foraging attempts while taking less than $6 \%$ lethally on average at each site. Yellow perch were a predominate prey item in number and biomass at both locations. Walleye made up a small proportion of the diet at both locations. However, both walleye and yellow perch abundance increased significantly $(p<0.05)$ at Drummond lsland. Walleye abundance at age 3 increased to record levels in 2008 following 3 years of cormorant management at Brevoort Lake. The estimated cormorant consumption of age- 1 walleye in the absence of management at Brevoort Lake during 2005 would account for $55 \%$ of the record 2006 age- 1 walleye population. These results support the hypothesis that cormorant predation on spawning aggregations of sportfish was a significant mortality factor and cormorant management reduced sportfish mortality and increased abundance at both locations. Continuation of harassment programs and fishery assessments will determine whether improvement of targeted sport îsheries through control of sping migrating cormorants is sustainable.
\end{abstract}

Published by Elsevier B.V.

\section{Introduction}

The interior population of double-crested cormorant (Phalacrocorax auritus; hereafter cormorant) has shown a substantial resurgence over the past 35 years (Wires and Cuthbert, 2006). Cormorants have increased from approximately 32,000 breeding pairs in the mid1970 s to more than 226,000 breeding pairs (including the Great Lakes states and provinces) by the mid-1990s (Wires and Cuthbert, 2006). The increase in the interior population of cormorants has caused perceived and known impacts to both commercial and natural resources (Taylor and Dorr, 2003).

Cormorants have caused documented impacts locally to recreational fisheries (Fielder, 2008; Johnson and Rakoczy, 2004; Rudstam et al., 2004). VanDevalk et al. (2002) found that cormorant

\footnotetext{
* Corresponding author.

E-mail address: brian.s.dorr@aphis.usda.gov (S.D. Brian).
}

consumption of age 1-2 yellow perch (Perca flavescens) could reduce future angler harvest of yellow perch and to a lesser extent, walleyes (Sander vitreus). Rudstam et al. (2004) indicated that cormorants were a major factor contributing to the decline in walleye and yellow perch populations in Oneida Lake, New York. Fielder (2008) concluded that cormorants were an influential factor affecting a collapse in the yellow perch sport fishery in the Les Cheneaux Islands, Lake Huron, Michigan: Research also indicates that much of this predation on yellow perch and walleye occurs in the spring. presumably when these species are aggregated during spawning and potentially more vulnerable to predation (Diana et al., 2006; Fielder, 2008; Rudstam et al., 2004).

Drummond Island and Brevoort Lake, Michigan are locations where spring predation by cormorants on spawning yellow perch and walleye was considered to potentially impact those sport fisheries. Fish community assessments have been made in St. Marys River (SMR) from 1975 to 2007, which includes Potagannissing Bay adjacent to Drummond Island, Michigan (Fielder et al., 2007). In a 2002 study of

0380-1330/\$ - see front matter. Published by Elsevier B.V. doi:10.1016;j.jglt:2010.02.001 
population characteristics within the SMR, total annual mortality for yellow perch increased and growth rate improved for both yellow perch and walleye in the Potagannissing Bay reach of the SMR (Fielder et al. 2003). Concomitant with the increase in yellow perch mortality and increased growth rate was the concern of increased predation by cormorants as one of several factors potentially affecting the fish population and fishery (Fielder et al., 2003).

At Brevoort Lake walleye abundance, survival, and recruitment have been monitored regularly by the U.S. Forest Service (USFS) and Michigan Department of Natural Resources (MDNR) since the early 1980s. During 1980-1983 the walleye fishery in Brevoort Lake was maintained by stocking fry and fingerlings as there was little natural reproduction (MDNR unpublished data). Average survival of stocked fingerlings to spawning ages 3 and 4 was 5-28\% resulting in a sustainable sport fishery (Bassett, 2006).

A spawning reef was constructed in 1984 and a 1989 fishery assessment found that $49 \%$ of the adult walleye population in the lake originated from natural reproduction (Bassett, 2006). Due to these findings, walleye stocking was discontinued from 1990 to 1996. Subsequent assessments indicated adequate reproduction of walleye but unlike the pre-reef period, survival to spawning ages 3 and 4 was poor (1-3\%; Bassett, 2006). Consequently, numbers of adult walleye declined steadily after 1991, even after walleye stocking was resumed in 1997.

Fishery assessments from 1994 to 2005 indicated high mortality of walleye was occurring between fall age- 0 and spring age-3 corresponding to total lengths of $13-36 \mathrm{~cm}$. Estimated numbers of spring age-3 walleye declined from a high of 3084 in 1986 to a low of 52 in 2005 (C. Bassett USFS, unpublished data). This decline occurred despite substantial natural reproduction and stocking of age-0 walleye between 1991 and 2003 (C. Bassett USFS, unpublished data). Walleye in the affected size range could not be legally harvested by anglers ( $38 \mathrm{~cm}$ minimum length limit) and there were no apparent changes in habitat characteristics or fish community composition that explained higher mortality of young walleye (C. Bassett USFS, unpublished data). However, daily cormorant sightings on the lake increased from less than 20 during the mid 1980 s to several hundred by the mid-1990s (C. Bassett USFS, unpublished data). Due to the aforementioned declines in sport fisheries at these locations spring cormorant harassment programs were initiated by the U.S. Department of Agriculture, Michigan Wildife Services (WS) at Drummond Island in 2004 and Brevoort Lake in 2005.

Fear-provoling harassment methods are non-lethal management techniques used when target species are mobile and damage occurs over a limited time period (e.g. spawning fish and migrating birds). Fearprovoking stimuli (e.g., propane cannons, Mylar tape, human effigies) can protect small areas, although their effects usually are temporary (Conover, 2002). Fear-provolking harassment methods are sometimes integrated with limited lethal take to prevent habituation to harassment techniques (Conover, 2002). Harassment techniques such as boat chases and pyrotechnics have been successfully implemented to protect local fishery resources in New York (Chipman et al., 2000). However these techniques when applied to multiple locations can be logistically difficult, labor intensive, and experisive to implement effectively.

In order to address the logistics and cost, the U.S. Department of Agriculture, Michigan Wildlife Services (WS) impiemented a variation of harassment techniques in which volunteer designated agents (DAs), are enlisted to protect fishery resources under the provision of the US Fish and Wildlife Services Public Resource Depredation Order (USFWS, 2003). This cooperative effort allows WS to leverage their staff and financing and expand their operations to multiple areas experiencing conflict with migrating cormorants.

The harassment programs at Drummond Island and Brevoort Laike were designed to protect spawning assemblages of walleye and yellow perch from cormorant predation during spring migration. Harassment programs included the use of non-lethal techniques (e.g. pyrotechnics, boat chases) reinforced with limited lethal take. The underlying hypothesis was that predation by spring migrating cormorants was a limiting mortality factor on walleye and yeliow perch at these locations. The objective of this study was to evaluate the effectiveness of harassment programs with respect to reducing foraging by migrating cormorants and to evaluate fishery response using data from ongoing fishery and fish population monitoring programs.

\section{Methods}

\section{Study area}

Drummond Island is located between the Upper Peninsula of Michigan, Chippewa County, and Ontario, Canada (Fig. 1). The SMR
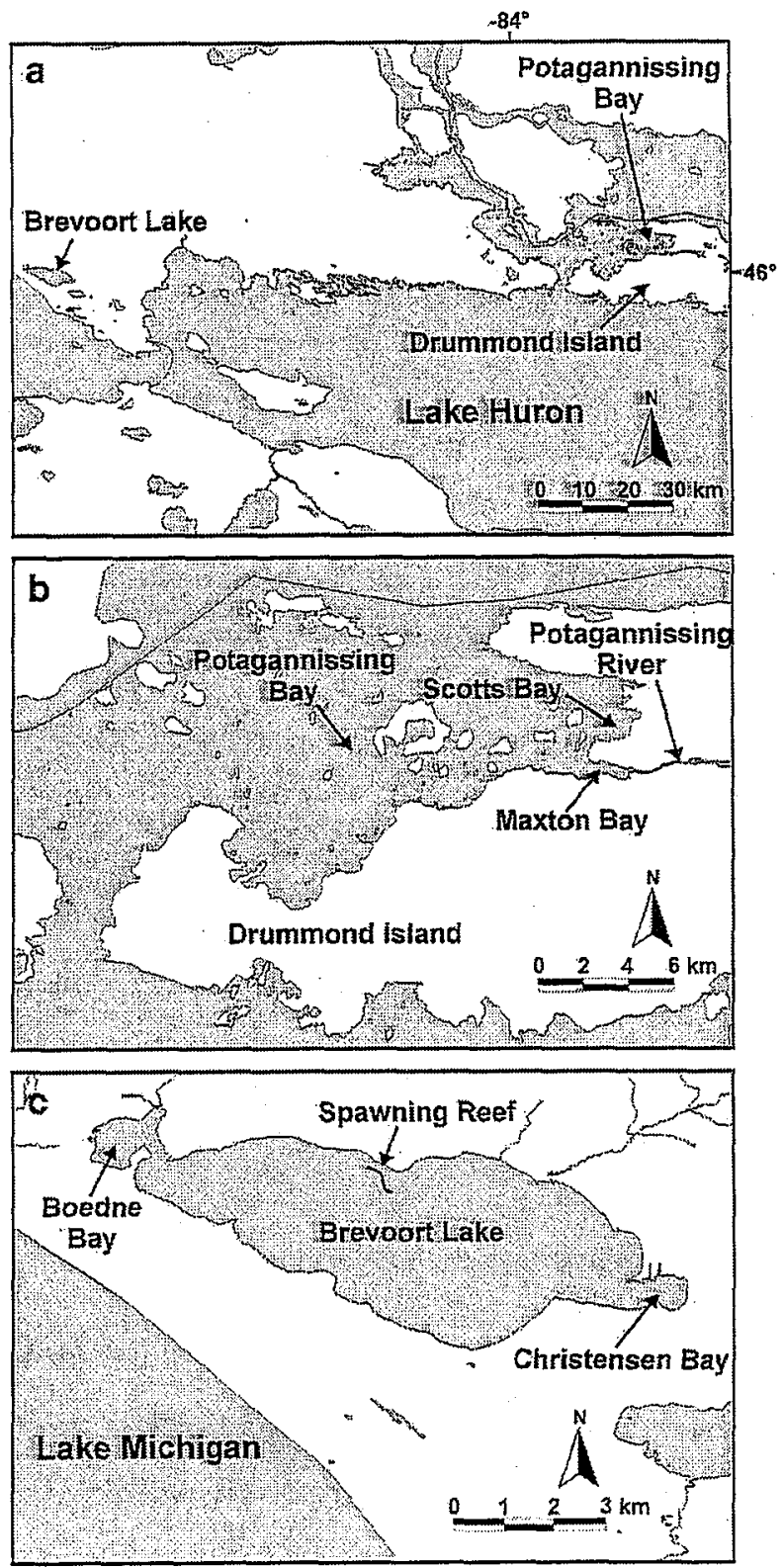

Fig. 1. a) Locations of Brevoort Lake and Drummond Island, MI. b) Scotts Bay and Maxton Bay spring harassment sites of double-crested comorants evaluated in 2004-2007, Drummond Island, Ml. c) Brevoort Lake, MI, artificial spawning reef, Boedne Bay, and Christensen Bay spring harassment sites of double-crested cormorants evaluated in 2005-2007, M! 
flowing down from Lake Superior divides with water flowing South into Lake Huron and East to the North Channel. The mouth of the Potagannissing River, Scott Bay and Maxton Bay were used for spring harassment and food habits collection sites on Drummond lsland. The area is shallow with a maximum depth of about $4 \mathrm{~m}$ and a total area of about 342 ha. Brevoort Lake has a surface area of 1712 ha and is located on the USFS, Hiawatha National Forest, Mackinac County, Michigan (Fig. 1). Most of the shoreline is forested and shallow areas and shoals are primarily sandy grading to pulpy peat in deeper water. The lake is relatively shallow with a maximum depth of about $10 \mathrm{~m}$. Both Brevoort Lake and Drummond Island have a variety of fish species with the primary sportfish species being walleye, yellow perch, northern pike (Esox lucius), and smallmouth bass (Micropterus dolomieu).

\section{Harassment evaluation}

Harassment was initiated in 2004 at Drummond Island and 2005 at Brevoort Lake and occurred each year between April 9 and May 13 , from dawn to dusk: Participants maintained a log of the number of cormorants observed, start and end times, number of cormorants killed, number recovered, number of shot shells used, and number of pyrotechnics used. A harassment period is defined as the time an individual(s) started active harassment to the time they were either replaced by another individual(s) or active harassment ended (e.g: all cormorants left or dusk). Total hours of harassment represent the total person hours (i.e. 2 people at $4 \mathrm{~h}$ each $=8 \mathrm{~h}$ ). Harassment intensity is reported as the average hours of active harassment effort per hectare per day (h/ha/d) at each site for all years. Wildlife Services staff or DAs estimated the numbers of cormorants in each flock dispersed, and the number that were not successfully dispersed (i.e. were able to forage) during each period. Estimates for each period were summed to provide the total number of foraging attempts made by cormorants at a given site and date. Similarly, estimates for each period were summed to provide the total number of non-deterred foraging attempts. The net number of foraging attempts deterred was used as a measure of the effective harassment effort in terms of percentage reduction in foraging attempts.

\section{Estimation of cormorant foraging}

Estimating the total number of foraging attempts at a spring harassment site likely overestimates the number of individual cormorants attempting to forage at a given site. This is due to the fact that an individual cormorant may repeatedly try to forage in a given harassment location. To address this issue of overestimation peak instantaneous counts adjusted for turnover rate were used to provide an estimate of the number of individual cormorants using a site (Lehnen and Krementz, 2005).

To avoid double counting cormorants, instantaneous counts were used from one observer per location per period. The observer scanned the harassment site at the beginning of each harassment period and recorded the number of cormorant observed at that time. Only cormorants within the harassment area whether on the water or flying were counted. Maxton Bay and Scotts Bay were the harassment sites at Drummond Island (Fig. 1) and could be scanned from a single location by land or boat. Cormorants at Brevoort Lake were counted by driving a boat across the lake to observe the entire area. The focus of harassment activities were Boedne Bay, Christensen Bay, and the artificial spawning reef (Fig. 1) although cormorants were harassed over the extent of the lake. The maximum instantaneous count of cormorants deterred during the harassment period from any one observer was used as the minimum number of cormorants present at the site. The peak instantaneous count of cormorants reported as not deterred from foraging at the end of each harassment period from any one observer was used as the peak total not deterred.
Movements of birds can cause instantaneous counts to underestimate actual numbers of individuals in a given area (Granholm, 1983; Lemen and Krementz, 2005). Therefore, peak instantaneous counts were adjusted upward by the average daily turnover rate $(0.282)$ at stopover sites of cormorants during spring migration based on satellite telemetry data (data source: USDA, Wildlife Services, National Wildlife Research Center, J.D. Taylor II). Stopover duration is the length of time that a migrating bird remains at a stopover location during migration (Piersma, 1987). The total number of individual cormorants using a spring harassment location was calculated as:

$T N=\sum\left(I D C^{*}(1+A D T R)\right)$

where: $T N=$ total number of individual cormorants during the harassment period, IDC= peak instantaneous daily count, and ADTR = average daily turnover rate at spring migration stopovers.

The total number of cormorants represents the total number of cormorant days of predation that could have occurred in the absence of harassment. Therefore fish consumption estimates are a projection of the maximum that could have been consumed based on observed counts and diet data. The net number deterred from foraging represents the effective harassment effort in terms of reduction in cormorant days of foraging. An ANOVA with Tukey's Studentized range (HSD) test was used to evaluate the differences in mean daily instantaneous cormorant counts between years for each location (Proc GLM, SAS, 1994).

\section{Consumption estimates}

\section{Food habits}

Stomachs were collected from up to 10 cormorants each day of spring harassment. Cormorants were shot with 12 gauge shotguns using non-toxic shot. Immediately after collection stomachs were preserved by injecting $60 \mathrm{ml}$ of formalin and stored in labeled bags on ice until samples could be stored in a freezer.

Procedures described by Bur et al. (1999) were followed for food habit analysis. Contents of each stomach were removed and weighed. Each prey item was identified from whole, partial (e.g. backbone with flesh), and fragments (otoliths and diagnostic bones) of specimens. Total length of prey items was measured to the nearest millimeter. Standard and backbone lengths from partially digested fish were converted to total lengths from standard equations and fish weights were determined from length weight regressions (Bayley and Austen; 1987; Bur etal., 1999; Cameron et al., 1973; Carlander, 1969; Knight et al., 1984; ODNR, 1997, 2005; Schneider et al., 2000; Wesley, 1996, and Great Lakes Science Center, Lake Huron unpublished data).

Estimates of total number and biomass prey consumed each year were based on:

$T=d \times F \times n_{i} \times N$

where $T=$ total number of prey $i$ consumed per harassment period $j$, and $d=$ number of days during the harassment period $j, n_{i}=$ mean number of prey $i$ per harassment period $j$, and $N=$ total number of cormorants per harassment period $j$;

$F=0.55 \mathrm{~kg} / \mathrm{g}_{\mathrm{i}}$

where $F=$ number of daily feedings per harassment period $j$, $g_{i}=$ mean weight of stomach contents per harassment period $j$, and $0.55 \mathrm{~kg}=$ mean daily food consumption per cormorant (Seefelt, 2005); and

$B=T \times w_{i}$

where $B=$ biomass of prey $i$ during harassment period $j$ and $w_{i}=$ mean weight of prey $i$ during harassment period $j$. 
Daily food consumption (DFC) of $0.55 \mathrm{~kg} /$ cormorant was taken from Seefelt (2005) for adult cormorants during the pre-nesting/ incubation period. In the absence of DFC data specific to spring migrating cormorants the pre-nesting/incubation period data were used to best represent energetic needs. These consumption estimates differed from Bur et al. (1999) in that all cormorants were considered to be adult migrating cormorants.

\section{Drummond Island fishery assessment}

Data from the 2002 and 2006 MDNR SMR fishery assessments were used to evaluate fishery response to the cormorant harassment program at Drummond Island. Comparisons between assessment periods included only the Potagannissing Bay data from the SMR because the mouth of the Potagannissing River, Maxton Bay, and Scotts Bay are important spawning locations for walleye and yellow perch and are within the Potagannissing Bay assessment area. The 2002 and 2006 assessments were used because they had the same gill-net mesh sizes so catch-per-unit-of-effort (CPUE) was fully comparable between years. The sample size was 10 net sets at the same locations each year. A t-test was used to determine significant $(p<0.05)$ differences in CPUE between assessment years. We conducted Levene's test for equality of variances and report approximate $t$ values using individual sample variance and Satterthwaite's approximate df values in cases of unequal variance (Norusis, 1990). Total annual mortality derived from catch curve analyses was qualitatively compared between assessment years for yellow perch.

\section{Brevoort Lake walleye assessment}

Data from spring trap-netting during 1985-2008 were used to assess effects of cormorant harassment on abundance of adult walleye (ages 3 and older). Shortly after ice-out, 5-6 nets were set on the Black Point spawning reef and one net was set in Cliristensen's Bay or the mouth of the Little Brevoort River. The reef is the primary spawning site in the lake but pre-spawn congregations of walleye occasionally occur at the other sites. Nets were inspected daily except when high winds prevented access. Walleye captured for the first time were marked with an upper caudal fin clip. All walleye were transported about $0.8 \mathrm{~km}$ from the net site for processing and release. Abundance was estimated by the Schnabel multiple census method (Ricker, 1975). Age and growth analysis from scale samples provided the basis for walleye population estimates by age groups. Beyond age 6 , two or more age groups were often combined due to the difficulty of accurately aging scales from older walleye.

Fall electrofishing data collected during 2006-2008 and periodically through the 1990 s provided additional information on abundance and survival of juvenile walleye. Electrofishing was conducted during early October with a Smith-Root SR-16 unit operating at 10$12 \mathrm{~A}$ pulsed DC. Sampling occurred in depths of $0.61-2.13 \mathrm{~m}$ at water temperatures ranging from about 10 to $15.6^{\circ} \mathrm{C}$. Length of shoreline
Table 2

Location, dates of harassment, date of peak estimated number of double-crested cormorants observed, total estimated number of cormorants observed and total estimated deterred from foraging over the harassment period, at Brevoort Lake, MI, 2005-2007 and Drummond Island, MI, 2004-2007. Numbers of individual cormorants were estimated from peak instantaneous daily counts adjusted for average daily turnover rate.

\begin{tabular}{lllll}
\hline Location & $\begin{array}{l}\text { Dates of } \\
\text { harassment }\end{array}$ & $\begin{array}{l}\text { Daily peak } \\
\text { count date }\end{array}$ & $\begin{array}{l}\text { Total number } \\
\text { of commorants }\end{array}$ & $\begin{array}{l}\text { Total number of } \\
\text { cormorants } \\
\text { deterred from } \\
\text { foraging }\end{array}$ \\
\hline $\begin{array}{c}\text { Brevoort } \\
\text { Lake } \\
\text { Brevoort } \\
\text { Lake }\end{array}$ & $4 / 16$ to $5 / 12,2005$ & $4 / 24 / 2005$ & 18,495 & 17,855 \\
$\begin{array}{c}\text { Brevoort } \\
\text { Lake }\end{array}$ & $4 / 13$ to $5 / 13,2006$ & $4 / 25 / 2006$ & 2349 & 1709 \\
$\begin{array}{c}\text { Drummond } \\
\text { Island }\end{array}$ & $4 / 22$ to $5 / 11,2007$ & $4 / 28 / 2007$ & 3179 & 2376 \\
$\begin{array}{c}\text { Drummond } \\
\text { Island }\end{array}$ & $4 / 13$ to $5 / 12,2005$ & $4 / 23 / 2005$ & 9446 & 7687 \\
$\begin{array}{c}\text { Drummond } \\
\text { Island }\end{array}$ & $4 / 9$ to $5 / 12,2006$ & $5 / 3 / 2006$ & 5200 & 2928 \\
Drummond & $4 / 20$ to $5 / 12,2007$ & $4 / 27 / 2007$ & 13,346 & 10,147 \\
Island & & 46,409 & 3382 \\
\hline
\end{tabular}

sampled ranged from 5.5 to $8.4 \mathrm{~km}$. Abundance of age- 0 and age-1 walleye captured by electrofishing was estimated by the Serns method (Serns, 1982, 1983). Survival of age-0 and age-1 walleye was determined from the Sems' estimates, Michigan DNR stocking records and subsequent Schnabel estimates of adult abundance.

\section{Results}

\section{Drummond Island harassment evaluation}

There was a total of $989 \mathrm{~h}(\overline{\mathrm{x}}=247 /$ period, $S D=103)$ of harassment between April 9 and May 13, for 2004-2007 (Table 1). Averaged over all year mean intensity of effort was $0.03 \mathrm{~h} / \mathrm{ha} / \mathrm{d}$ $(S D=0.01)$. The total number of shotgun shells used was 3495 $(\bar{x}=874$ /period, $S D=439)$, the total pyrotechnics used was 1558 $(\vec{x}=390 /$ period, $S D=378)$, and total number of cormorants killed was $719(\bar{x}=180$ /period, $S D=89$ : Table 1$)$. The total number of cormorant foraging attempts estimated for 2004-2007 was 105,905 $(\bar{x}=26,476 /$ period, $S D=28,850)$. The total net foraging attempts deterred were $95,653(\bar{x}=23,913 /$ period, $S D=28,252)$ with on average $90 \%$ of the total foraging attempts deterred (Table 1). Mean instantaneous counts per harassment period between April 9 and May 13 , from 2004 to 2007 was 312 cormorants ( $S D=473$ ).

Based on instantaneous daily counts and daily turnover rate, a total of $64,401(\bar{x}=16,100 /$ period, $S D=13,912)$ individual cormorants were estimated to have attempted to forage from 2004 to 2007 (Table 2). Of the estimated total a net of $54,344(\bar{x}=13,586 /$ period, $S D=13,663$ ) individual cormorants were prevented from foraging by

Table 1

Total number of double-crested cormorant foraging attempts (i.e. individual cormorants may have been harassed $>1$ time), total foraging attempts prevented, harassment effort, number of shotgun shells and pyrotechnics used, and number of cormorants taken lethally from Brevoort Lake, Ml, 2005-2007 and Drummond lsland, Mi, $2004-2007$.

\begin{tabular}{|c|c|c|c|c|c|c|}
\hline Location & $\begin{array}{l}\text { Dates of } \\
\text { harassment }\end{array}$ & $\begin{array}{l}\text { Total foraging } \\
\text { attempts }\end{array}$ & $\begin{array}{l}\text { Total foraging attempts } \\
\text { prevented }(\%)\end{array}$ & $\begin{array}{l}\text { Harassment } \\
\text { effort }(h)\end{array}$ & $\begin{array}{l}\text { Number of shells } \\
\text { used (pyrotechnics) }\end{array}$ & $\begin{array}{l}\text { Number of } \\
\text { cormorants taken }\end{array}$ \\
\hline Brevoort Lake & $4 / 16$ to $5 / 12,2005$ & 22,286 & $21,621(97)$ & 1784 & $1854(1400)$ & 637 \\
\hline Bravoort Lake & $4 / 13$ to $5 / 13,2006$ & 8218 & $6435(78)$ & 1181 & $901(839)$ & 271 \\
\hline Brevoort Lake & $4 / 17$ to $5 / 11,2007$ & 9924 & $8074(81)$ & 1153 & $1503(746)$ & 380 \\
\hline Drummond island & $4 / 22$ to $5 / 13.2004$ & 69.124 & 65.722 (95) & 311 & $1374(661)$ & 293 \\
\hline Drummond lsland & $4 / 13$ to $5 / 12,2005$ & 14,022 & $12,339(88)$ & 352 & $924(769)$ & 188 \\
\hline Drummond Island & $4 / 9$ to $5 / 12.2006$ & 5584 & $3527(63)$ & 200 & $893(54)$ & 162 \\
\hline Drummond lsland & $4 / 20$ to $5 / 12,2007$ & 17,175 & $14,065(82)$ & 126 & $304(74)$ & 76 \\
\hline
\end{tabular}




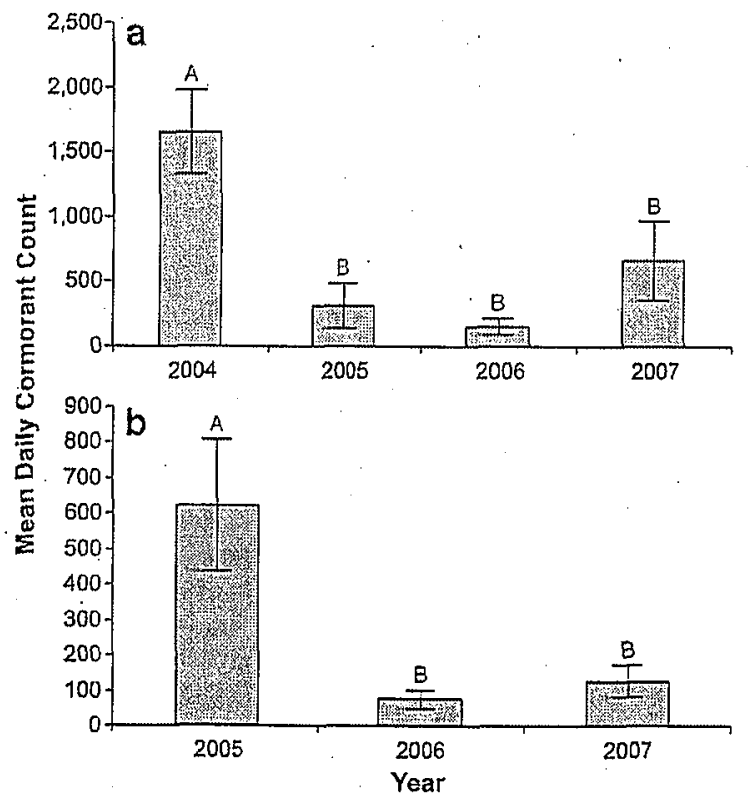

Fig. 2. a) Mean daily counts (bars) of double-crested comorants using the Drummond Island area of Lake Huron. Ml, during spring migration 2004-2007. b) Mean daily counts (bars) of double-crested cormorants using Brevoort Lake, MI, during spring migration 2005-2007. Vertical lines represent 95\% confidence interval estimates. Bars with different letters are significantly different $(p<0.05)$ from each other.

harassment efforts (Table 2). Peak foraging attempts for 2004-2007 occurred between April 23rd, and May 3rd (Table 2). Mean daily counts of cormorants declined significantly (2-way ANOVA, $F_{3,102}=$ $43.51, p=<0.0001$ ) in years subsequent to initiation of harassment (Fig. 2). On average about $1.1 \%$ of the total estimated individual number of cormorants were taken lethally (including food habits collections) during the harassment programs.
Brevoort Lake harassment evaluation

There was a total of $4118 \mathrm{~h}(\tilde{\mathrm{x}}=1373 /$ period, $S \mathrm{SD}=357 /$ period $)$ of harassment from April 16 to May 13, from 2005 to 2007 (Table 1). Averaged over all years mean intensity of effort was $0.03 \mathrm{~h} / \mathrm{ha} / \mathrm{d}$ $(S D=0.01)$. The total number of shotgun shells used was 4258 ( $\bar{x}=1419 /$ period, $S D=482 /$ period $)$, the total pyrotechnics used was 2985 ( $\bar{x}=995 /$ period, $S D=354 /$ period ), and total number of. cormorants killed was $1288(\bar{x}=429 /$ period, $S D=188 /$ period; Table 1). The total number of cormorant foraging attempts estimated for the period $2005-2007$ was $40,428(\tilde{x}=13,476 /$ period, $S D=7677 /$ period). The total net foraging attempts deterred were 36,130 $(\bar{x}=2043 /$ period, $S D=8335 /$ periocl $)$, with on average $89 \%$ of total foraging attempts deterred (Table 1). Mean instantaneous counts per' harassment period between April 16 and May 13, from 2005 to 2007 was 75 cormorants ( $S D=158$ ).

Based on instantaneous daily counts and daily turnover rate a total of $24,023(\bar{x}=8008 /$ period, $S D=9092 /$ period $)$ individual cormorants were estimated to have attempted to forage for 2005-2007 (Table 2). $A$ net of $21,970(\bar{x}=7323 /$ period, $S D=9153 /$ period $)$ individual cormorants were prevented from foraging by harassment efforts. Peak foraging attempts for 2005-2007 occurred between April 24th and April 28th (Table 2). Mean daily counts of foraging cormorants declined significantly (2-way ANOVA, $F_{2}, 83=29.06, p=<0.0001$ ) in years subsequent to the initiation of harassment (Fig. 2). On average about $5.4 \%$ of the total estimated individual number of cormorants were taken lethally during the harassment programs.

\section{Food habits Drummond Island}

The cormorant diet near Drummond Island during 2005 and 2006 (April-May) consisted of 13 species and two taxonomic groups Coregonidae (generally whitefish Coregonus clupeaformis) and Catostomidae (mostly white sucker Catostomus commersoni) (Table 3 ). Cormorant diets were made up primarily of yellow perch during both years. Because diet data were not collected in 2004 and 2007 the average observed diet from collections conducted in 2005-2006 were used to estimate cormorant prey consumption for 2004 and 2007.

Table 3

Projected annual number and biomass of prey that would have been consumed in the absence of harassment by all cormorants observed compared to actual observed consumption of foraging cormorants (in parentheses) in Drummond island, Lake Huron, Ml, 2004-2007. Only taxa with >1\% relative abundance shown (except for walleye). Unidentified species also not included.

\begin{tabular}{|c|c|c|c|c|c|c|c|c|}
\hline \multirow[t]{2}{*}{ Species (common name) } & \multicolumn{4}{|c|}{ Number (thousands)/year } & \multicolumn{4}{|c|}{ Biomass $(\mathrm{kg}) /$ year } \\
\hline & $2004^{3}$ & 2005 & 2006 & $2007^{2}$ & $2004^{2}$ & 2005 & 2006 & $2007^{a}$ \\
\hline Coregonidae (whitefishes) & $\begin{array}{l}4.3 \\
(0.3)\end{array}$ & $\begin{array}{l}2.7 \\
(0.4)\end{array}$ & $\begin{array}{l}0.0 \\
(0.0)\end{array}$ & $\begin{array}{l}1.7 \\
(0.3)\end{array}$ & $\begin{array}{l}645.0 \\
(39.1)\end{array}$ & $\begin{array}{l}400.9 \\
(58.2)\end{array}$ & $\begin{array}{l}0.0 \\
\quad(0.0)\end{array}$ & $\begin{array}{l}248.3 \\
(46.4)\end{array}$ \\
\hline Esox lucius (northern pike) & $\begin{array}{l}4.3 \\
(0.3)\end{array}$ & $\begin{array}{l}1.8 \\
(0.3)\end{array}$ & $\begin{array}{l}0.4 \\
(0.1)\end{array}$ & $\begin{array}{l}1.7 \\
(0.3)\end{array}$ & $\begin{array}{l}658.7 \\
(39.9)\end{array}$ & $\begin{array}{l}163.8 \\
(23.8)\end{array}$ & $\begin{array}{l}98.5 \\
(33.6)\end{array}$ & $\begin{array}{l}253.5 \\
(47.4)\end{array}$ \\
\hline Notropis hudsonius (spottail shiner) & $\begin{array}{l}17.2 \\
(1.0)\end{array}$ & $\begin{array}{l}5.3 \\
(0.8)\end{array}$ & $\begin{array}{l}2.1 \\
(0.7)\end{array}$ & $\begin{array}{l}6.6 \\
(1.2)\end{array}$ & $\begin{array}{l}84.6 \\
(5.1)\end{array}$ & $\begin{array}{l}23.2 \\
(3.4)\end{array}$ & $\begin{array}{l}11.8 \\
(4.0)\end{array}$ & $\begin{array}{l}32.6 \\
(6.1)\end{array}$ \\
\hline Cyprinidae (minnows/carp) & 144.8 & $\begin{array}{l}49.0 \\
(7.1)\end{array}$ & $\begin{array}{l}16.4 \\
(5.6)\end{array}$ & $\begin{array}{l}55.7 \\
(10.4)\end{array}$ & $\begin{array}{l}1035.0 \\
(62.7)\end{array}$ & $\begin{array}{l}296.7 \\
(43.1)\end{array}$ & $\begin{array}{l}138.6 \\
(47.2)\end{array}$ & $\begin{array}{l}398.4 \\
(74.5)\end{array}$ \\
\hline Catosromidae (suckers) & $\begin{array}{l}127.6 \\
(7.7)\end{array}$ & $\begin{array}{l}16.9 \\
(2.5)\end{array}$ & $\begin{array}{l}25.0 \\
(8.5)\end{array}$ & $\begin{array}{l}49.1 \\
(9.2)\end{array}$ & $\begin{array}{l}8759.4 \\
(530.5)\end{array}$ & $\begin{array}{l}1590.7 \\
(231.0)\end{array}$ & $\begin{array}{l}1529.2 \\
(521.1)\end{array}$ & $\begin{array}{l}3371.3 \\
(630.3)\end{array}$ \\
\hline Ameiunus nebulosus (brown bullhead) & $\begin{array}{l}1.4 \\
(0.1)\end{array}$ & $\begin{array}{l}0.9 \\
(0.1)\end{array}$ & $\begin{array}{l}0.0 \\
(0.0)\end{array}$ & $\begin{array}{l}0.6 \\
(0.1)\end{array}$ & $\begin{array}{l}228.1 \\
(13.8)\end{array}$ & $\begin{array}{l}141.8 \\
(20.6)\end{array}$ & $\begin{array}{l}0.0 \\
(0.0)\end{array}$ & $\begin{array}{l}87.8 \\
(16.4)\end{array}$ \\
\hline Centrarchidae (sunfishes) & $\begin{array}{l}31.5 \\
(1.9)\end{array}$ & $\begin{array}{l}18.7 \\
(2.7)\end{array}$ & $\begin{array}{l}0.4 \\
(0.1)\end{array}$ & $\begin{array}{l}12.1 \\
(2.3)\end{array}$ & $\begin{array}{l}204.1 \\
(12.4)\end{array}$ & $\begin{array}{l}121.8 \\
(17.7) \text {. }\end{array}$ & $\begin{array}{l}2.0 \\
(0.7)\end{array}$ & $\begin{array}{l}78.6 \\
(14.7)\end{array}$ \\
\hline Perca flavescens (yellow perch) & $\begin{array}{l}411.4 \\
(24.9)\end{array}$ & $\begin{array}{l}120.3 \\
(17.5)\end{array}$ & $\begin{array}{l}54.3 \\
(18.5)\end{array}$ & $\begin{array}{l}158.3 \\
(29.6)\end{array}$ & $\begin{array}{l}9448.2 \\
(572.2)\end{array}$ & $\begin{array}{l}1941.0 \\
(281.9)\end{array}$ & $\begin{array}{l}1488.3 \\
(507.2)\end{array}$ & $\begin{array}{l}3636.4 \\
(679.8)\end{array}$ \\
\hline Sander vitreus (walleye) & $\begin{array}{l}2.9 \\
(0.2)\end{array}$ & $\begin{array}{l}1.8 \\
(0.3)\end{array}$ & $\begin{array}{l}0.0 \\
(0.0)\end{array}$ & $\begin{array}{l}1.1 \\
(0.2)\end{array}$ & $\begin{array}{l}130.3 \\
(7.9)\end{array}$ & $\begin{array}{l}81.0 \\
(11.8)\end{array}$ & $\begin{array}{l}0.0 \\
(0.0)\end{array}$ & $\begin{array}{l}50.2 \\
(9.4)\end{array}$ \\
\hline Other spp. & $\begin{array}{l}11.5 \\
(0.7)\end{array}$ & $\begin{array}{l}4.5 \\
(0.6)\end{array}$ & $\begin{array}{l}1.1 \\
(0.4)\end{array}$ & $\begin{array}{l}4.4 \\
(0.8)\end{array}$ & $\begin{array}{l}37.0 \\
(2.2)\end{array}$ & $\begin{array}{l}9.9 \\
(1.4)\end{array}$ & $\begin{array}{l}5.3 \\
(1.8)\end{array}$ & $\begin{array}{l}14.2 \\
(2.7)\end{array}$ \\
\hline Total & $\begin{array}{l}756.9 \\
(45.8)\end{array}$ & $\begin{array}{l}221.9 \\
(32.2)\end{array}$ & $\begin{array}{l}99.7 \\
(34.0)\end{array}$ & $\begin{array}{l}291.3 \\
(54.5)\end{array}$ & $\begin{array}{l}21,230.4 \\
(1285.8)\end{array}$ & $\begin{array}{l}4770.6 \\
(692.9)\end{array}$ & $\begin{array}{l}3273.7 \\
(1115.6)\end{array}$ & $\begin{array}{l}8171.0 \\
(1527.6)\end{array}$ \\
\hline
\end{tabular}

\footnotetext{
a Diet data were not collected in 2004 and 2007. The average cormorant diet composition for 2005-2006 was used for 2004 and 2007 estimates.
} 
Projected numerical consumption of all fish species by cormorants in the absence of harassment ranged from 99.7 to 756.9 thousand/year and was 3 to 8 fold higher in 2004 than in 2005-2007 (Table 3). Numerically yellow perch, Cyprinidae, and Catostomidae were the most plentiful diet items. Projected biomass consumed by cormorants ranged from 3273.7 to $21,230.4 \mathrm{~kg} /$ year and was 3 to 6 -fold higher in 2004 compared to 2005-2007 (Table 3). The projected biomass of prey consumed followed a similar trend as abundance with yellow perch, Catostomidae, and Cyprinidae comprising the greatest weight of prey consumed. The projected biomass of yellow perch consumed in 2004 was $9448.2 \mathrm{~kg}$ and in 2006 was $1488.3 \mathrm{~kg}$. The projected biomass of walleye consumed in 2004 was $130.3 \mathrm{~kg}$. No walleye were found in the diet in 2006. Numerical consumption by foraging cormorants only was on average 8 -fold less than projected foraging activity by all cormorants in the absence of harassment activities (Table 3). Estimated biomass consumed by foraging cormorants only was on average 8-fold less than projected foraging by all cormorants in the absence of harassment activities (Table 3).

\section{Food habits Brevoort Lake}

The cormorant diet at Brevoort Lake during 2005-2007 included more than 20 fish species and 1 crustacean. Brevoort Lake cormorants consumed an average of $8.6,18.0$, and 12.1 prey items daily per individual collected in 2005-2007, respectively. Projected numerical consumption of all fish species by cormorants ranged from 108.4 to 1472.0 thousand/year and was 7 to 14-fold higher in 2005 than in 2006 and 2007 (Table 4). Yellow perch were the most abundant prey consumed by cormorants and comprised more than $67 \%$ of prey items in all years. Craynish (Astacidae) also were numerically abundant in all years ( $\geq 5 \%$ of diet) but comprised more than $17 \%$ of the diet in 2005 . Walleye comprised less than $1 \%$ of prey items by number for all years.

Projected biomass consumed by cormorants in the absence of harassment ranged from 1311.6 to $10,639.3 \mathrm{~kg} /$ year and was 6 to 8 fold higher in 2005 compared to 2006 and 2007 (Table 4). Projected biomass trends were similar to numerical trends, with yellow perch

Table 4

Projected annual number and biomass of prey that would have been consumed in the absence of harassment by all cormorants observed compared to actual observed consumption of foraging cormorants (in parentheses) in Brevoort Lake, M! 2005-2007. Only. taxa with $>1 \%$ relative abundance are shown (except for walleye). Unidentified species also not included.

\begin{tabular}{|c|c|c|c|c|c|c|}
\hline \multirow[t]{2}{*}{ Species (common name) } & \multicolumn{3}{|c|}{$\begin{array}{l}\text { Number (thousands)/ } \\
\text { year }\end{array}$} & \multicolumn{3}{|c|}{ Biomass $(\mathrm{kg}) /$ year } \\
\hline & 2005 & 2006 & 2007 & 2005 & 2006 & 2007 \\
\hline Astacidae (crayfish) & $\begin{array}{l}260.3 \\
(6.7)\end{array}$ & $\begin{array}{l}9.4 \\
(2,0)\end{array}$ & $\begin{array}{l}5.2 \\
(1.0)\end{array}$ & $\begin{array}{l}624.8 \\
(16.1)\end{array}$ & $\begin{array}{l}22.5 \\
(4.8)\end{array}$ & $\begin{array}{l}12.5 \\
(2.5)\end{array}$ \\
\hline Esox lucius (northern pike) & $\begin{array}{l}9.3 \\
(0.2)\end{array}$ & $\begin{array}{l}0 \\
(0)\end{array}$ & $\begin{array}{l}0.2 \\
(<0.1)\end{array}$ & $\begin{array}{l}1075.3 \\
(27.7)\end{array}$ & $\begin{array}{l}0 \\
(0)\end{array}$ & $\begin{array}{l}18.3 \\
(3.6)\end{array}$ \\
\hline $\begin{array}{l}\text { Neogobius melanostomus } \\
\text { (round goby) }\end{array}$ & $\begin{array}{l}21.7 \\
(0.6)\end{array}$ & $\begin{array}{l}11.5 \\
(2.5)\end{array}$ & $\begin{array}{l}1.2 \\
(0.2)\end{array}$ & $\begin{array}{l}356.0 \\
(9.2)\end{array}$ & $\begin{array}{l}183.3 \\
(38.9)\end{array}$ & $\begin{array}{l}19.3 \\
(3.8)\end{array}$ \\
\hline $\begin{array}{l}\text { Percopsis omiscomaycus } \\
\text { (trout-perch) }\end{array}$ & $\begin{array}{l}7.7 \\
(0.2)\end{array}$ & $\begin{array}{l}2.8 \\
(0.6)\end{array}$ & $\begin{array}{l}1.9 \\
(0.4)\end{array}$ & $\begin{array}{l}25.2 \\
(0.6)\end{array}$ & $\begin{array}{l}9.1 \\
(1.9)\end{array}$ & $\begin{array}{l}6.2 \\
(1.2)\end{array}$ \\
\hline $\begin{array}{l}\text { Cottus bairdii } \\
\text { (mottled sculpin) }\end{array}$ & $\begin{array}{l}72.8 \\
(1.9)\end{array}$ & $\begin{array}{l}0.4 \\
(0.1)\end{array}$ & $\begin{array}{l}0 \\
(0)\end{array}$ & $\begin{array}{l}291.3 \\
(7.5)\end{array}$ & $\begin{array}{l}2.3 \\
(0.5)\end{array}$ & $\begin{array}{l}0 \\
(0)\end{array}$ \\
\hline Centrarchidae (sunfishes) & $\begin{array}{l}9.3 \\
(0.2)\end{array}$ & $\begin{array}{l}2.2 \\
(0.5)\end{array}$ & $\begin{array}{l}9.2 \\
(1.8)\end{array}$ & $\begin{array}{l}668.0 \\
(17.2)\end{array}$ & $\begin{array}{l}88.3 \\
(18.8)\end{array}$ & $\begin{array}{l}498.5 \\
(98.2)\end{array}$ \\
\hline $\begin{array}{l}\text { Perca flavescens } \\
\text { (yellow perch) }\end{array}$ & $\begin{array}{l}1067.7 \\
(27.5)\end{array}$ & $\begin{array}{l}166.3 \\
(35.3)\end{array}$ & $\begin{array}{l}86.9 \\
(17.1)\end{array}$ & $\begin{array}{l}6481.9 \\
(166.8)\end{array}$ & $\begin{array}{l}860.9 \\
(183.0)\end{array}$ & $\begin{array}{l}822.8 \\
(162.0)\end{array}$ \\
\hline Sander vitreus (walleye) & $\begin{array}{l}13.9 \\
(0.4)\end{array}$ & $\begin{array}{l}1.6 \\
(0.4)\end{array}$ & $\begin{array}{l}0.6 \\
(0.1)\end{array}$ & $\begin{array}{l}165.0 \\
(4.2)\end{array}$ & $\begin{array}{l}62.3 \\
(13.2)\end{array}$ & $\begin{array}{l}161.4 \\
(31.8)\end{array}$ \\
\hline Other spp. & $\begin{array}{l}9.3 \\
(0.2)\end{array}$ & $\begin{array}{l}3.4 \\
(0.7)\end{array}$ & $\begin{array}{l}3.2 \\
(0.6)\end{array}$ & $\begin{array}{l}951.8 \\
(24.5)\end{array}$ & $\begin{array}{l}82.9 \\
(17.6)\end{array}$ & $\begin{array}{l}156.0 \\
(30.7)\end{array}$ \\
\hline Total & $\begin{array}{l}1472.0 \\
(37.9)\end{array}$ & $\begin{array}{l}197.6 \\
(34.0)\end{array}$ & $\begin{array}{l}108.4 \\
(21.2)\end{array}$ & $\begin{array}{l}10,639.3 \\
(273.8)\end{array}$ & $\begin{array}{l}1311.6 \\
(278.7)\end{array}$ & $\begin{array}{l}1695.0 \\
(333.8)\end{array}$ \\
\hline
\end{tabular}

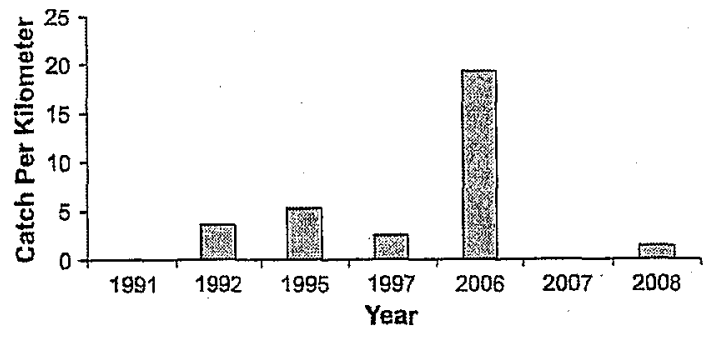

Fig. 3. Fall electrofishing record of numbers of age- 1 walleye in Brevoort Lake, MI, 1991-2008.

comprising the greatest biomass (49-66\%). Northern pike was the next largest contributor to projected biomass in 2005, whereas round goby (Neogobius melanostomus) and Centrarchidae were in 2006 and 2007, respectively. Numerical consumption by foraging cormorants only was over all years 19 -fold less than the projected foraging activity by all cormorants in the absence of harassment activities (Table 4). Estimated biomass consumed by foraging cormorants only was reduced by 39 -fold in 2005 and about 5-fold in 2006 and 2007 (Table 4). Mean total length of yellow perch consumed by cormorants was 78, 71, and $91 \mathrm{~mm}$ in 2005, 2006, and 2007, respectively. Mean total length of walleye consumed by cormorants was 106,139 , and $309 \mathrm{~mm}$ in 2005 through 2007 , respectively.

\section{Drummond Island fishery}

Mean survey net CPUE for yellow perch was significantly greater ( $t_{9.5}=-2.2, p=0.04 ; t_{\mathrm{df}}$ adjusted for unequal variances) in 2006 $(\bar{x}=62.9, \mathrm{SE}=23.5)$ than $2002(\bar{x}=7.5, \mathrm{SE}=3.9)$. Mean survey net CPUE for walleye was significantly greater $\left(t_{18}=-2.5, p=0.02\right)$ in $2006(\bar{x}=6.5, \mathrm{SE}=1.6)$ than $2002(\overline{\mathrm{x}}=1.8, \mathrm{SE}=1.0)$. Catch curve analyses of mortality for yellow perch increased from 0.57 to 0.96 from 2002 to 2006 . There were not enough walleye sampled across age classes to produce mortality estimates using catch curve analyses.

\section{Brevoort Lake fishery}

Fall 2006 electrofishing walleye catch was 3.7 times that of the previous high catch rate $(19.25 / \mathrm{km}$ vs $5.27 / \mathrm{km})$ dating back to 1991 (Fig. 3). Survival of the 2003 walleye year-class to age- 5 was 5 fold higher post management than survival of the 2000 walleye year-class to age -5 (Table 5). Spring 2008 netting $(N=24$ ) yielded the second highest adult (age-3 and older) walleye population estimate 7780 ( $95 \% \mathrm{Cl}=6633-9413$ ) recorded for this lake (Fig. 4). Ninety percent of the adult population consisted of the 2005 year-class which was the first year-class fully recruited following initiation of management.

Table 5

Estimated cohort survival of stocked walleye fingerlings in Brevoort Lake, Ml.

\begin{tabular}{|c|c|c|c|c|c|c|}
\hline \multirow[t]{2}{*}{ Year-class } & \multirow{2}{*}{$\begin{array}{l}\text { Number } \\
\text { stocked }\end{array}$} & \multirow{2}{*}{$\begin{array}{l}\text { Year of } \\
\text { evaluation }\end{array}$} & \multirow[t]{2}{*}{ Age } & \multicolumn{3}{|c|}{ Number of aduits } \\
\hline & & & & $\begin{array}{l}\text { Total } \\
\text { catch }\end{array}$ & $\begin{array}{l}\text { Population } \\
\text { estimate ( } 95 \% \text { C.I.) }\end{array}$ & $\begin{array}{l}\text { Percent } \\
\text { survival }\end{array}$ \\
\hline 1997 & 20,534 & 2001 & 4 & 18 & $90(30-94)$ & 0.4 \\
\hline \multirow[t]{2}{*}{2000} & 22,665 & 2004 & 4 & 9 & $44(14-46)$ & 0.2 \\
\hline & & 2005 & 5 & 10 & $16(10-41)$ & 0.1 \\
\hline 2003 & 19433 & 2008 & 5 & 44 & $90(56-235)$ & 0.5 \\
\hline
\end{tabular}

a Percent survival in all years may be overestimated because adult population estimates include naturally reproduced fish which could not be distinguished from stocked fish. 


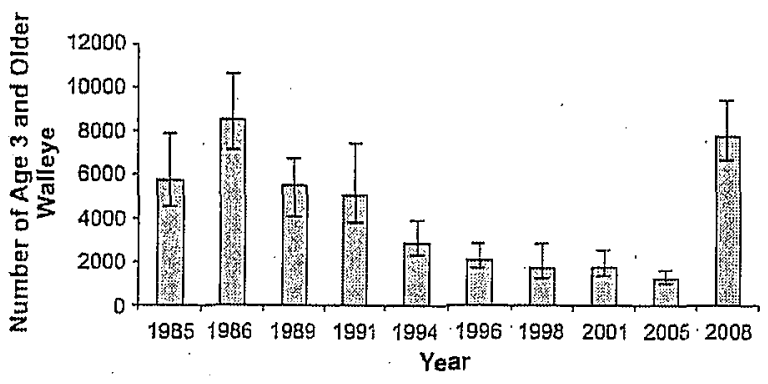

Fig. 4. Spring population estimares and 95\% confidence intervals (vertical lines) for age-3 and older walleye in Brevoort Lake 1985-2008. Double-crested cormorant management was initiated in spring 2005.

\section{Discussion}

\section{Harassment}

Effectiveness of cormorant harassment efforts varied between sites and years ranging from $60 \%$ to $97 \%$ of foraging attempts deterred within a season. However, on average over both sites, $90 \%$ of cormorant foraging attempts were deterred due to harassment activities. In addition there was a significant $(p<0.05) 79 \%$ deciine in the average estimated number of cormorants over both sites for years subsequent to initiation of harassment programs. Average intensity of effort was similar at both sites at $0.03 \mathrm{~h} / \mathrm{ha} / \mathrm{d}$ of harassment effort. Both sites declined in use of shotgun shells, pyrotechnics, and numbers of cormorants taken lethally subsequent to initiation of harassment. The overall decline in numbers may have been affected by control efforts of breeding cormorants in the Les Cheneaux lslands ( $\mathrm{LCl}$ ), Lake Huron, Michigan and declines in breeding populations of cormorants in the North Channel of Lake Huron, Ontario, CA. Control efforts have been effective in reducing breeding cormorant numbers by more than $73 \%$ in the LCI from 2004 to 2008 and this may affect the use of Brevoort Lake and Drummond Island sites. However, control efforts did not affect the decline in observed numbers of cormorants on breeding colonies as rapidly as the decline seen at harassment locations. The more rapid decline at harassed sites suggests that harassment alone may have some interannual effect on use of the spring stopover sites. This inter-annual decine suggests that cormorants modified migratory behavior to avoid harassed sites with the effect of making the programs more effective and likely reducing lethal take of cormorants. Further research would be necessary to evaluate the possibility of modification of migratory behavior due to management specific to migrating cormorants. Regardless of the causes of the anriual decline in number of cormorants, the combined non-lethal harassment reinforced by limited lethal harassment was effective in deterring a large percentage of cormorants at these sites within each year.

Cormorants displayed little temporal variation in use of each site between years. Peak counts of cormorants at both sites occurred between April 23rd and April 28th of each year, with the exception of Drummond Island in 2006, when peak counts occurred on May 3rd. in most cases there was a relatively rapid buildup in numbers and a pronounced peak in numbers of cormorants moving though each area and then a more gradual decline in use. This information on temporal pattern could help in refining harassment programs to maximize effectiveness in limiting cormorant foraging.

Estimates of the individual number of cormorants using Brevoort Lake and Drummond Island adjusted upward for turnover rate averaged about $62 \%$ of the total number of estimated foraging attempts. On average less than $5.4 \%$ of the cormorants migrating through each site were taken lethally, based on the estimated number of individual cormorants observed. As with the estimated number of individual cormorants using each site, the estimated $\mathrm{kg}$ of fish consumed declined substantially from 2004 levels at Drummond Island and 2005 at Brevoort Lake.

Food habits and fishery response

\section{Drummond Island}

Comparisons of survey net CPUE of yellow perch and walleye in Potagannissing Bay indicate significantly greater abundance of both species in 2006 (post-cormorant management) than 2002 (precormorant management). Mortality estimates for walleye specific to Potagannissing Bay are not available as the sample size was not large enough to develop a bay specific mortality estimate. Mortality estimates from catch. curve analysis indicate mortality of yellow perch increased over the same period. However this increase could be an artifact of unequal recruitment because of the strong 2003 year-class entering the age structure (Fielder et al., 2007). The violation of the constant recruitment assumption seems likely given that the yellow perch mortality estimate ( $96 \%$ ) would not be sustainable and should result in a decline in yellow perch in Potagannissing Bay.

Diet data indicate cormorants consumed 1.36 times the biomass and 9 times the number of yellow perch harvested in the Potagannissing Bay open water fishery of 1999 (Fielder et al., 2002). While the fishery and cormorant consumption data are not directly comparable due to differences in age classes predated or harvested and the absence of yellow perch population data, they suggest a potential recruitment issue for the fishery. This is supported by research showing compensatory processes affecting yellow perch survival have occurred by age-1, and mortality is largely additive on total mortality (Forney, 1980; Nielsen, 1980; Rudstam et al., 2004). Additionally, the age-1. cohort size is a good predictor of the number of adult yellow perch recruiting to the fishery (Forney, 1980; Rudstam et al., 2004). These data combined with more detailed demographic data on the perch fishery in Potagannissing Bay may clarify possible effects of cormorant consumption of sub-adult yellow perch.

There are a number of factors that can affect the yellow perch and walleye populations other than cormorant predation. Percid reproductive success greatly increased in all of Lake Huron starting in 2003, presumably due to the collapse of alewives (Fielder et al., 2008). The lack of reliable cohort-specific mortality data make the determination of whether there are more walleye and yellow perch because of better reproductive success, lower mortality, or a combination of these factors difficult (O'Gorman and Burnett, 2001). Given these caveats trends in yellow perch and walleye abundance are also consistent with the underlying hypotheses that cormorants are a limiting mortality factor and reduction of cormorant caused mortality can increase the abundance of selected fish stocks. Future St. Marys River fishery assessments may provide a clearer picture of the effects of cormorant harassment in Potagannissing Bay.

\section{Brevoort Lake}

Estimates of cormorant consumption of prey based on abundance and biomass declined from 2005 to 2007 in Brevoort Lake, mirroring declines in cormorant abundance and foraging attempts. Cormorants consumed a diversity of prey in Brevoort Lake which is consistent with other food habit studies and supports previous observations that cormorants are opportunistic feeders (e.g. Ludwig et al., 1989). Age-0 and age- 1 yellow perch $(<90 \mathrm{~mm})$ were the dominant prey item in all years in Brevoort Lake. Declines in total yellow perch consumed (abundance and biomass) since the initiation of control measures have been observed. However, the evaluation of the impacts of changes in cormorant predation is difficult because very little data on the yellow perch fishery exist at Brevoort Lake.

Walleye comprised numerically less than $1 \%$ of the cormorant prey items in 2005-2007, yet this likely was a significant portion of the existing walleye population in Brevoort Lake. An estimated 13,900 
walleye, comprised mostiy of age- 1 fish, were projected to have been consumed in the absence of harassment in 2005. Compared to the 17 year record age- 1 walleye year-class of $2006(25,480)$ this level of cormorant predation would account for $55 \%$ of the total age-1 population. Cormorants on Brevoort Lake consumed walleye in size classes corresponding to age- 1 and age- 2 . The primarily additive mortality (Rudstam et al., 2004) and cumulative effects of cormorant predation on a large percentage of age- 1 and age- 2 walleye in multiple year-classes are sufficient to account for observed declines in recruitment to the spawning population and sport fishery from the mid-1990s to 2005.

Cormorant diets indicated reduced individual consumption in 2005 when cormorant numbers were highest. After control measures were initiated, the number of prey items consumed by each cormorant increased as cormorant numbers declined. This increase in number of prey items consumed by individual cormorants may reflect increased abundance of prey items and consequently increased foraging efficiency. Reduced intraspecific competition due to management caused deciines in cormorant numbers may also have increased individual foraging efficiency (Lewis et al., 2001). The size of yellow perch and walleye consumed also increased over the management periot. The increased survival of walleye to older age classes and consequently greater abundance of larger fish may have shifted the mean weight of walleye consumed by cormorants upward. The larger size of individual yellow perch consumed suggests increased survival and abundance of yellow perch although empirical fishery data are lacking.

The record 2005 walleye year-class in Brevoort Lake could not have happened unless environmental conditions favored high egg hatching success and fry survival. However, additional periods favoring high walleye egg hatching success were likely over the 17 year monitoring period, but this success was not reflected in increased recruitment to age-3 or older age classes. Cormorant predation on this lake only occurs for about a month during the spring. Consequently, this predation has little orno directinfluence on walleye survival until the second and third years of life (ages 1 and 2) when walleye are large enough to be of interest to cormorants relative to other food sources such as yellow perch. The results of this study suggest that sustained cormorant harassment allowed substantially higher survival of walleye to age-3 than would have occurred otherwise.

Cormorant food habitats (this study) and numbers of cormorants observed on Brevoort Lake during the harassment effort suggest that cormorant predation is a viable explanation for the sharp decline in walleye survival to spawning age that occurred during the 1990 s. The unprecedented high survival of the first walleye year-class (2005) to be protected from heavy cormorant predation by a harassment effort provides further evidence of a link between cormorant abundance and walleye survival in Вгеvoort Lake.

Record numbers of age -3 walleye in 2008 may reflect the dual effects of reduced predation by cormorants on juvenile walleye and reduced competition and predation by other fish species (including adult walleye). Ten to 15 years of heavy cormorant predation may have suppressed the entire fish community in Brevoort Lake, reducing the potential for competitive and predatory interactions between juvenile walleye and other species (Rudstam et al., 2004). In a sense, a "vacuum" is created in the fish community that can be filled by the first strong yearclass of any species that is no longer subject to cormorant predation.

Additional years of monitoring are needed to determine if the rebound of the Brevoort Lake walleye fishery will be sustained. The dominant 2005 walleye year-class will exert substantial competitive and predatory influence on succeeding walleye year-classes for several years. Electrofishing catch data indicate low walleye reproduction since 2005 (Fig. 3). Competitive influences of increases in populations of other fish species such as yellow perch also reduce the probability of having another large walleye year-class during the next few years. An increase in yellow perch is supported anecdotally by anglers reporting much improved fishing success for yellow perch since 2005 (C. Bassett USFS, unpublished data.). In the long term, a return to more consistent walleye reproduction at moderate levels would indicate sustained benefits of cormorant harassment. These results on Brevoort Lake suggest that sustained harassment of cormorants on inland lakes can improve suppressed walleye fisheries.

Because cormorant harassment programs were conducted concurrent with evaluation efforts, by necessity projected cormorant consumption estimates were used. These estimates should be interpreted as the maximum amount of prey that could have been consumed in the absence of harassment. Thus, projected consumption at both sites may overestimate what would happen if management had not been implemented. This overestimation could occur for example if cormorant consumption of a fish species or species cohort reduced the population density to the point where the density was no longer energetically profitable for cormorants to consume them. In the case of reduced prey density cormorants would likely switch to other prey or forage elsewhere. This change in foraging would be reflected in changes in the diet of unharassed cormorants over time as the prey base was depleted. Conversely, if the targeted fish species were not being consumed and observed numbers of cormorants were low then projected fish consumption estimates would be negligible. This result would exonerate cormorants as an influencing factor on targeted fish populations. The projected consumption estimates in this study clearly indicate that cormorants are capable of consuming a large proportion of certain age classes and possibly fish populations even when the species or age class makes up a small percentage of the cormorant diet.

Non-lethal harassment programs using designated agents and supplemented with limited lethal control have been successful in reducing cormorant predation in this study. Harassment resulted in both reduced predation within years and significant $(p<0.05)$ reductions in predation between years. Evaluation of diet data indicated that sportfish were being consumed in numbers and biomass that could impact recruitment to the fishery. Fishery data for both sites indicated that targeted fish populations increased in abundance concomitant with the decline in cormorant predation. Fisheries response in this study is consistent with the underlying hypothesis that cormorant predation was a significant mortality factor. However, cormorants are only one of many possibie factors affecting these fisheries. Continuation of harassment programs and fishery assessments will determine whether improvement of targeted sport fisheries through cormorant control is sustainable.

Harassment programs are not applicable in all cases. Brevoort Lake and Drummond Island reflect situations were a combination of factors converge that make harassment a viable management method. These factors include vulnerable spawning fish stociss, a relatively limited area to be harassed, a large number of migratory fish-eating cormorants arriving concurrent with spawning, and a pool of deciicated and willing volunteers to undertake the considerable harassment effort. Cormorant management may not be needed or effective in all situations and alternative factors should be considered carefully prior to establishing control programs.

\section{Aclonowledgments}

The USDA, Wildlife Services designated agents at Brevoort Lake and Drummond Island provided considerable time and effort in support of this research which are greatly appreciated. Extensive help in the field and with data collection and entry was provided by G. Rigney, P. Ryan, A. Wilson, J. Hill, T. Harris, S. Lemmons, K. Hanson, S. Woodruff, and P. Fioranelli. D. Fielder with Michigan DNR reviewed this manuscript and assisted with Drummond Island fishery data and analyses. K. Hanson, M. Smith, T. King, B. Blackwell, D. Schlosser, and 3 anonymous reviewers also provided helpful manuscript reviews. This article is Contribution 1581 of the USGS Great Lakes Science Center. 


\section{References}

Bassett, C.E., 2006. Decline of the Brevoort Lake walleye fishery: have cormorants played a role? United States Department of Agriculture, U.S. Forest Service, Hiawatha National Forest internal report. $9 \mathrm{pp}$.

Bayley, P.B., Austen, D.J., 1987. Comparative analysis of fish populations in Illinois impoundments: gear efficiencies and standards for condition factors. lll. Nat. Hist Surv. Aq. Biol, Section Tech. Rep, 87/14. Champaign, IL.

Bur, M.T., Tinnirello, S.L., Lovell, C.D., Tyson. J.T., 1999. Diet of the double-crested cormorant in western Lake Erie. In: Tobin, M.E. (Ed.). Technical coordinator. Symposium on double-crested cormorants: population stans and management issues in the midwest: USDA-APHIS Tech. Bull. 1879, pp. 73-85. Washington, DC

Cameron, J.N., Koscoris, J., Penhale, P.A., 1973. Preliminary energy budget of the ninespine stickleback (Pungitius pungitius) in an arctic lake.J Fish Res Bd Can 30, 1179-1189.

Carlander, K.D., 1969. Handbook of freshwater fishery biology, volume one. The lowa State University Press, Ames, IA.

Chipman, R.B., Riclımond, M.E., Gansowski, J.T., Preusser, K... Stang, D.L, Coleman, J. et al. 2000. Bada bang, bada boom: dispersal of fall migrating comorants to protect sporffish on Oneida Lake, New York. In: Brittingham, M.C, Kays, J., McPeake, $R$ (Eds.), Proc. of the Ninth Wild. Damage Mgmt. Conf., Pennsylvania State University, State College, PA, p. 46.

Conover, M.R., 2002. Resolving human-wildlife conflicts: the science of wildlife damage management. CRC Press, Boca Raton, FL

Diana, J.S., Maruca, S., Lowe. B.. 200G. Do increasing cormorant populations threaten sport fishes in the Great Lakes? A case study in Lake Huron.J Great Lakes Res 32, 306-320.

Fielder, D.C., 2008. Examination of factors contributing to the decline of the yellow perch population and fishery in Les Cheneaux Islands, Lalke Huron with emphasis on the role of double-crested cormorants, J Great Lakes Res 34, 506-523.

Fielder, D.G., Borgeson, D.f., Bowen, A.K., Koproski. S.R., Greenwood, S.J., Wright, G.M., 2003. Population dynamics of the St. Marys River fish community 1975-2002. Great Lakes Fish. Comm, Ann Arbor. http://www.glfc.org/lakecom/lhc/SMR2002rpt.pdf.

Fielder. D.G. Bowen, A.K., Gebhardt, K. J. Greenwood, S. 2002. Harvest of fishes in the St. Marys River, May, 1999 through March 2000. Great Lakes Fish. Comm, Ann Arbor. http://www.gifc,org/lakecom/lhc/lhchome.aspłpub.

Fielder, D.C., Liskauskas, A., Mohr, LC., Boase, J., 2008. Nearshore fish community. In: Bence, J.R, Mohr. LC. (Eds.), The state of Lake Huron in 2004. : Spec. Pub., 08-01. Great Lakes Fish. Comm, pp, 47-51.

Fielder. D.C., et al., 2007. Population dynamics of the St. Marys River fish community 1975-2006. Great Lakes Fisi. Comm, Ann Arbor. http://www.glfc.org/lakecom/ lhc/SMR2OOGrpt.pdif.

Forney, J.L., 1980. Evolution of a management strategy for the walleye in Oneida lake, New York. New York Fish and Game journal 27, 105-141.

Granholm. S.L. 1983. Bias in density estimates due to movement of birds. Condor 85 (243), 248

Johnson, J.E., Rakoczy, G.P., 2004. Investigations into recent declines in survival of brown trout stocked in Lake Charievoix and Thunder Bay, Lake Huron Michigan. Michigan Dept. of Nat. Res. Fish. Tech. Report 2075, Lansing, Ml.

Knight, RL., Margraf, F.j., Carline, R.F., 1984. Piscivory by walleyes and yellow perch in western Lake Erie. Trans Am Fish Soc 113, 677-693.

Lehnen, S.E., Krementz, D.G., 2005. Tumover rates of fall-migrating pectoral sandpipers in the Lower Mississippi Alluvial Valley. J Wild Manage 69, 671-680.
Lewis, S., Sherratt, T.N., Hanner, K.C., Wanless, S., 2001. Eviclence of intra-specific compecition for food in a pelagic seabird. Nature 412, 816-818.

Ludwig. J.F. . Hull, C.N., Luciwig. M.E., Auman, H.]., 1989. Food habits and feeding ecology of nesting double-crested cormorants in the upper Great Lakes, 1986-1989. JackPine Warbler 67, 114-126.

Nielsen. LA. 1980. Effect of walleye (Stizostedion vitreum vitreum) predation on juvenile mortality and recruitment of yellow perch (Perca flavescens) in Oneida Lake, New York. Can J Fisli Acquat Sci 37, 11-39.

Norusis, M.]. 1990. The SPSS guide to data analyses for release 4. SPSS Inc, Chicago, IL

ODNR (Ohio Department of Natural Resources), 1997. Ohio's Lake Erie Fisheries, 1996. ODNR, Federal Aid in Sport Fish Restoracion, Project F69-P, Ann. Rept., Columbus. $105 \mathrm{pp}$.

ODNR (Ohio Department of Natural Resources), 2005. Ohio's Lake Erie Fisheries, 2004 ODNR, Federal Aid in Sport Fish Restoration, Project F69-P, Ann. Repc., Columbius. $109 \mathrm{pp}$.

O'Gorman, R., Burnett, J.A.D., 2001. Fish community dynamics in Northeastern Lake Ontario with emphasis on the growth and reproductive success of yellow perch (Perca flavescens) and white yellow perch (Morone americana), 1978 to 1997. Great Lakes Res 27, 367-383.

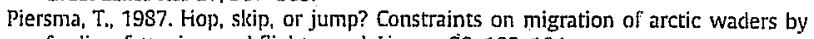
feeding, fattening, and flight speed. Limosa 60, 185-194.

Ricker, W.E., 1975. Bull. 191. Fish. Res, Board of Canada, Ottawa, Canada.

Rutdstam, L.G., VanDeValk, A.J., Adams, C.M., Coleman, J.T.H., Forney, J.L., Richmond. M. E., 2004. Cormorant predation and the population dynamics of walleye and yellow perch in Oneida Lake. Ecol Appl 14, 149-J63.

SAS Institute, 1994. SAS/STAT user's guide. SAS Institute, Cary. NC.

Schneider, I.C. Laarman, P.W., Gowing. H., 2000. length-weight relationships. Chapter 17. In: Schneider, James, C. (Eds.), Manual of fisheries survey methods II: with periodic updates. Michigan Dept. of Nat. Res, Fisheries Special Report 25, Ann Arbor.

Seefelt, N.E. 2005. Foraging ecology, bioenergetics and predatory impact of breeding couble crested cormorants (Phalacrocorax auritus) in the Beaver Archipelago, northern Lake Michigan. Diss., Michigan State University. Dept. of Zool.

Serns, S.L, 1982. Relationship of walleye fingering density and electrofishing carch per effort in northern Wisconsin lakes. N Am J Fish Momt 2,38-44.

Serns, 5.L., 1983. Relationship between electrofishing catch per unit effort and density of walleye yearlings. N Am ] Fish Mgmt 3, 451-452.

Taylor Il, J.D., Dorr, B., 2003. Double-crested cormorant impacts to commercial and natural Resources. In: Fagerstone, K., Witmer, $G$. (Eds.), Tentb Wild. Damage Mgmt. Conf. Proc, Hotsprings AR

USFWS (United States Fish and Wildlife Service), 2003: Federal Register. Department of Interior, Fish and Wildlife Service, Migratory Bird Permits. Regulations for double crested cormorant managenent, 68, pp. 12653-12660.

VanDeValk, A.J., Adams, C.M., Rudstam, L.C., Forney, J.L., Brooking, T.E., Gerken, M., et al., 2002. Comparison of anglei and cormorant harvest of walleye and yellow perch in Oneida Lake, New York. Trans Am Fish Soc 131, 27-39.

Wesley, J.K. 1996. Age and growth of chinool salmon in Lake Michigan: verification, current analysis, and past trends. M. Sc, thesis, University of Michigan. Ann Arbor.

Wires. L $R_{r}$ Cuthbert, FJ., 2006. Historic populations of the double-crested cormorant (Phalacrocorax auritus): implications for conservation and management in the 21st century. Waterbirds $29(9-37), 2006$. 